\title{
Analiza modalna bezprzedzialowego wagonu osobowego 150A w celu przystosowania jego struktury nośnej do wózkow wysokich prędkości typu 11 ANc
}

\begin{abstract}
$W$ artykule przedstawiono badania dotyczqce dynamiki strukturalnej bezprzedziatowego wagonu osobowego. Analiza skupiła się na odpowiedzi czy struktura nośna pudła wagonu typu 150C (150A) jest wystarczajaco sztywna, aby spetnić oczekiwania zwiqzane ze stabilizacja wężykowania obrotowego wózków a pomoca systemu hydraulicznych tlumików drgań oraz czy częstotliwości własne poszczególnych form drgań struktury nośnej rozważanego pudta sq wystarczajaco dobrze rozsynchronizowane ze spodziewanymi częstotliwościami wymuszeń. Badania numeryczne przeprowadzono za pomoca programu ABAQUS. Poszukiwano częstotliwości drgań własnych pudła wagonu w przedziale od 3 do $16 \mathrm{~Hz}$. Uzyskane wyniki poddano analizie i pokazano w formie graficznej. Artykut powstat w ramach projektu badawczo-rozwojowego $\mathrm{nr}$ R10 041 02, finansowanego przez Ministerstwo Nauki i Szkolnictwa Wyższego ze środków budżetowych na naukę na lata 2007:2009 pt. „,Wózek pasażerskiego pojazdu kolejowego typu Z o prędkości $250 \mathrm{~km} / \mathrm{h}$ i możliwości modyfikacji do prędkości $300 \mathrm{~km} / \mathrm{h}$ ”.
\end{abstract}

\section{Wprowadzenie}

Konwencjonalny pojazd szynowy podczas jazdy poddawany jest rozmaitym oddziaływaniom mechanicznym, powodujacym drgania nadwozia, które ze względu na charakter wymuszeń można sklasyfikować jako:

- drgania wywołane przez nierówności geometryczne toru (błędy w planie i profilu) oraz kół (np. bicie promieniowe czy poprzeczne),

- drgania wywołane przez sinusoidalny bieg zestawów kołowych $\mathrm{w}$ torze (wężykowanie obrotowe i poprzeczne).

Częstotliwości tych wymuszeń zależą m.in. od prędkości jazdy - im wyższa prędkość tym większa częstotliwość wymuszeń. Wymuszenia te przenoszone są przez strukturę pojazdu i wzbudzają drgania nadwozia w postaci: podskakiwania, galopowania, kołysania, wężykowania poprzecznego i wężykowania obrotowego. Drgania nadwozia wywołują z kolei drgania strukturalne pudła stalowego, przybierające liczne formy wyrażające się odkształceniami giętymi pionowymi i poprzecznymi pudła oraz deformacjami o charakterze postaciowym jego przekroju poprzecznego.

W kontekście bezpieczeństwa i komfortu jazdy istotne są drgania o częstotliwości do $10 \mathrm{~Hz}$. Szczególnie ważne jest to podczas projektowania pojazdów na duże prędkości jazdy, w których stosowane są urządzenia stabilizujące bieg wózków. Przy prędkościach ponad $200 \mathrm{~km} / \mathrm{h}$ wózki wężykują z częstotliwościami rzędu $8 \mathrm{~Hz}$. Z tymi też częstotliwościami urządzenia stabilizujące wywierają obciążenia dynamiczne na ustrój nośny pudła.
Do tego rodzaju pojazdów należy przyszły wagon osobowy, przystosowany do prędkości $250 \div 300 \mathrm{~km} / \mathrm{h}$ i będący przedmiotem zainteresowania niniejszej pracy.

Do przeprowadzenia badań homologacyjnych ma posłużyć wagon pomiarowy typu $150 \mathrm{C}$ (dawniej 150 A) będący w posiadaniu IPS „TABOR”, który w tym celu musi być odpowiednio zmodernizowany. Najistotniejszym elementem tej modernizacji będzie wymiana obecnych wózków typu $11 \mathrm{ANa}$ na wózki typu $11 \mathrm{ANc}$, specjalnie w tym celu zaprojektowane. Są to wózki o konwencjonalnej strukturze. Każdy z tych wózków ma na wyposażeniu cztery specjalne amortyzatory hydrauliczne, łączące ramę wózka $z$ ostoją nadwozia. Tworzą one system thumiący wężykowanie wózka, którego skuteczność uwarunkowana jest między innymi odpowiednią sztywnością nośników, jakimi w tym przypadku są rama wózka i pudło stalowe. Ewentualny niedostatek sztywności grozi tym, że amortyzatory zamiast rozpraszać energię wężykowania wózka (praca w zakresie małych skoków roboczych amortyzatorów) będą zachowywały się podobnie jak pręty sztywne, powodując kompensowanie ruchów wymuszających ze strony wózka na drodze sprężystej deformacji nośników.

Powyższe zagrożenie wymaga uważnego rozpatrzenia i znalezienia zawczasu odpowiednich środków zapobiegawczych. Stawia to przed konstruktorami wagonu potencjalny problem techniczny, jaki dotychczas z powodu braku odpowiednich narzędzi obliczeniowych nie mógł być rozwiązany w sposób w pełni świadomy i kontrolowany. 


\section{Przedmiot pracy i cel do osiągnięcia}

Niniejsza praca jest związana tematycznie $\mathrm{z}$ projektem badawczym nr R 10041 02, którego celem jest stworzenie wózka dla wagonu pasażerskiego na prędkość $250 \div 300 \mathrm{~km} / \mathrm{h}$. Realizacja tego projektu obejmuje między innymi przeprowadzenie pełnych badań homologacyjnych wg normy PN-EN 14363: 2005 [4], co wymaga stosownego przygotowania obiektu badawczego, jakim jest kompletny wagon. Homologacja dotyczy całego pojazdu, co oznacza, że nie tylko wózki, ale również nadwozie podlega ocenie pod względem własności dynamicznych. Powodzenie przedsięwzięcia zależy w dużym stopniu od wykrycia i usunięcia z konstrukcji pojazdu wszelkich wad konstrukcyjnych w kontekście jego własności dynamicznych już na etapie badań teoretycznych.

W ramach niniejszej pracy zostaną przeprowadzone stosowne badania teoretyczne, które udzielą odpowiedzi na następujące pytania zasadnicze:

- czy struktura nośna pudła wagonu typu 150C (150A) jest wystarczająco sztywna aby spełnić oczekiwania związane ze stabilizacją wężykowania obrotowego wózków za pomocą systemu hydraulicznych tłumików drgań

- czy częstotliwości własne poszczególnych form drgań struktury nośnej danego pudła są wystarczająco dobrze rozsynchronizowane ze spodziewanymi częstotliwościami wymuszeń. W przypadku wykrycia jakichkolwiek niedostatków w tym zakresie zostana zdiagnozowane ich przyczyny oraz wskazane sposoby przeciwdziałania. Niezależnie od tego wyniki pracy dostarczą cennych informacji i wskazówek dla konstruktorów nadwozi przyszłych wagonów osobowych, przystosowanych do wysokich prędkości.

Sztywność ramy wózka w kontekście skuteczności działania systemu tłumienia wężykowania obrotowego została wyznaczona w pracy OR-9239 [3], a uzyskany wynik został uwzględniony w obliczeniach symulacyjnych dynamiki wagonu OR-9228 [2], w związku z tym kwestia ta nie wymaga dalszego rozpatrywania $\mathrm{w}$ niniejszej pracy.

\section{Dane wyjściowe}

Do analizy przyjęto następujące dane i założenia:

- struktura i wymiary pudła stalowego - wg dokumentacji konstrukcyjnej wagonu typy 150A

- w skład masy nadwozia wchodzą:

- struktura pudła stalowego $(8700 \times 2) \quad 17400 \mathrm{~kg}{ }^{1)}$

- elementy wyposażenia pod pudłem $9718 \mathrm{~kg}^{2)}$

- podłoga z wykładzina $2800 \mathrm{~kg}^{3)}$

- okna $1300 \mathrm{~kg}{ }^{2)}$

- amplituda siły generowanej przez jeden amortyzator wężykowania obrotowego

$10000 \mathrm{~N}$

- zakres poszukiwanych częstotliwości drgań własnych

$3 \div 16 \mathrm{~Hz}$.

Do obliczeń numerycznych użyto pakietu programów metody elementów skończonych ABAQUS [1]. Analizę dynamiczna podzielono na dwa etapy. W pierwszym, wykorzystując procedure „Frequency”, obliczono częstotliwości i formy drgań własnych pudła wagonu w zakresie $3 \div 16 \mathrm{~Hz}$. W drugim, bazując na wynikach pierwszego etapu, zbadano przy pomocy procedury „Steady-state dynamics (Modal)” wpływ sił zmiennych generowanych przez amortyzatory wężykowania na drgania strukturalne pudła. W procedurze „Steady-state dynamice” zastosowano krytyczne thumienie równe 0,03 oraz wymuszające siły harmoniczne o wartości $10 \mathrm{kN}$, przyłożone do wsporników thumika wężykowania. Sposób przyłożenia sił od amortyzatorów wężykowania wymuszających drgania pudła przedstawiono na rys.2 oraz na rys.3.

Jako materiał przyjęto stal o module Younga równym $210 \mathrm{GPa}$ i gęstości $7850 \mathrm{~kg} / \mathrm{m}^{3}$. Zamodelowano wszystkie elementy mające wpływ na podatność konstrukcji na drgania. W pudle stalowym uwzględniono również obciążenia pochodzące od urządzeń zamocowanych pod wagonem (jako masy skupione) oraz wyposażenia wagonu (jako bezpostaciowe masy ciagłe). Model numeryczny podzielono na prawie 126 000 elementów powłokowych S4R. Podział pudła stalowego na elementy pokazano na rys.4. Podział na elementy w przekroju wzdłużnym części skrajnej wagonu przedstawiono na rys.5.

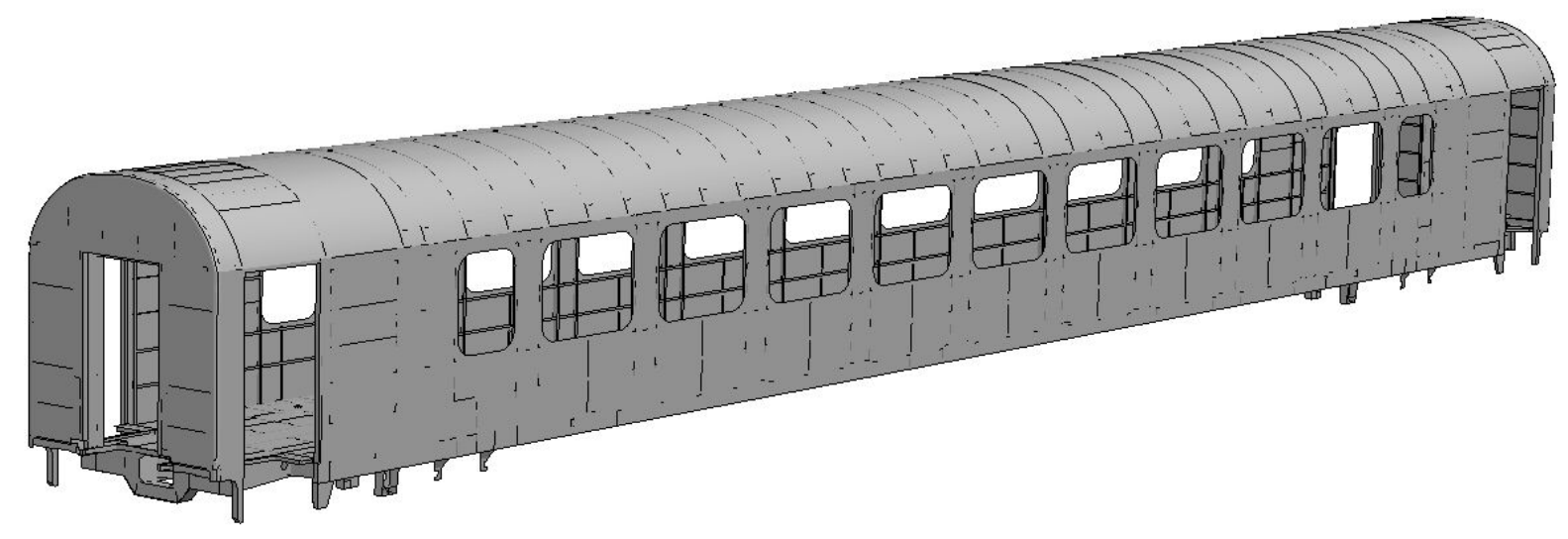

Rys. 1. Model numeryczny wagonu typu 150A 


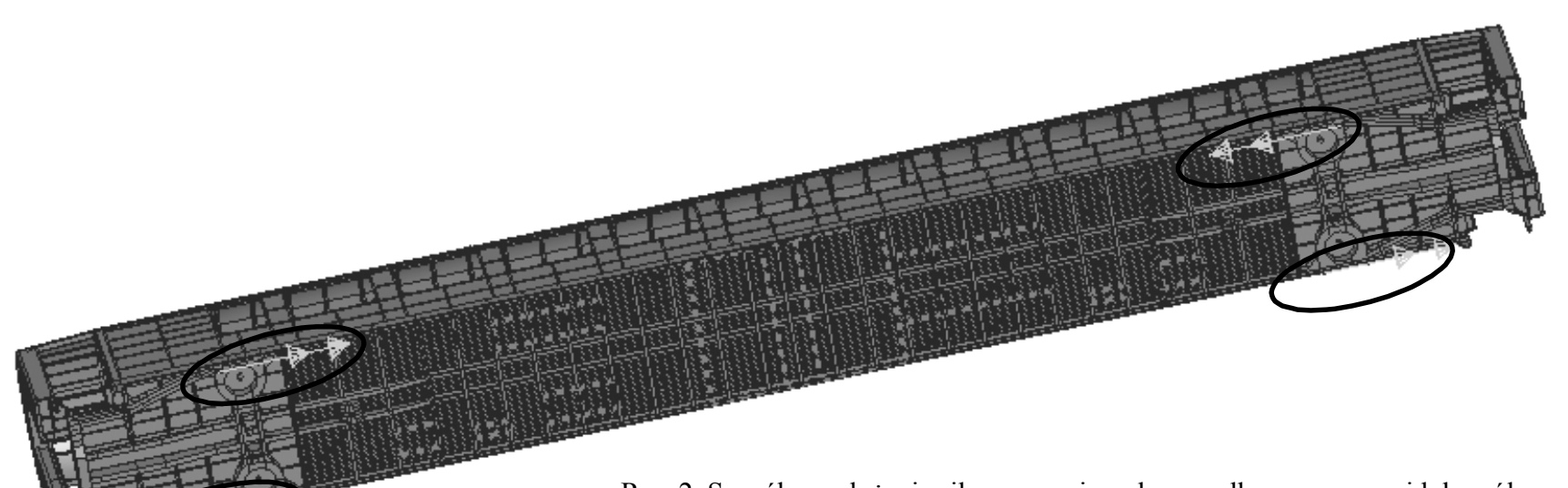

Rys. 2. Sposób przyłożenia sił wymuszających na pudło wagonu - widok ogólny

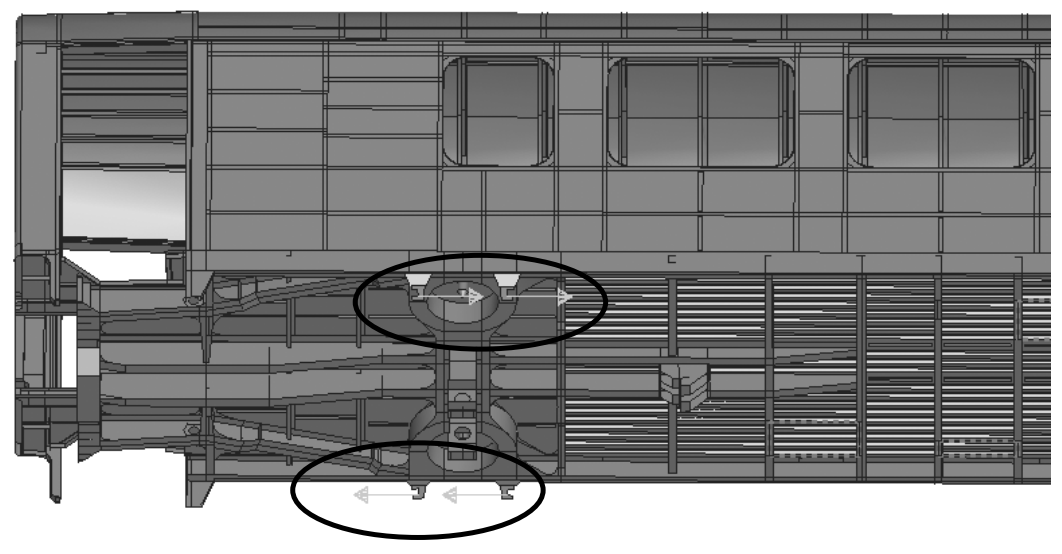

Rys. 3. Sposób przyłożenia sił wymuszających na pudło wagonu widok na belkę skrętową

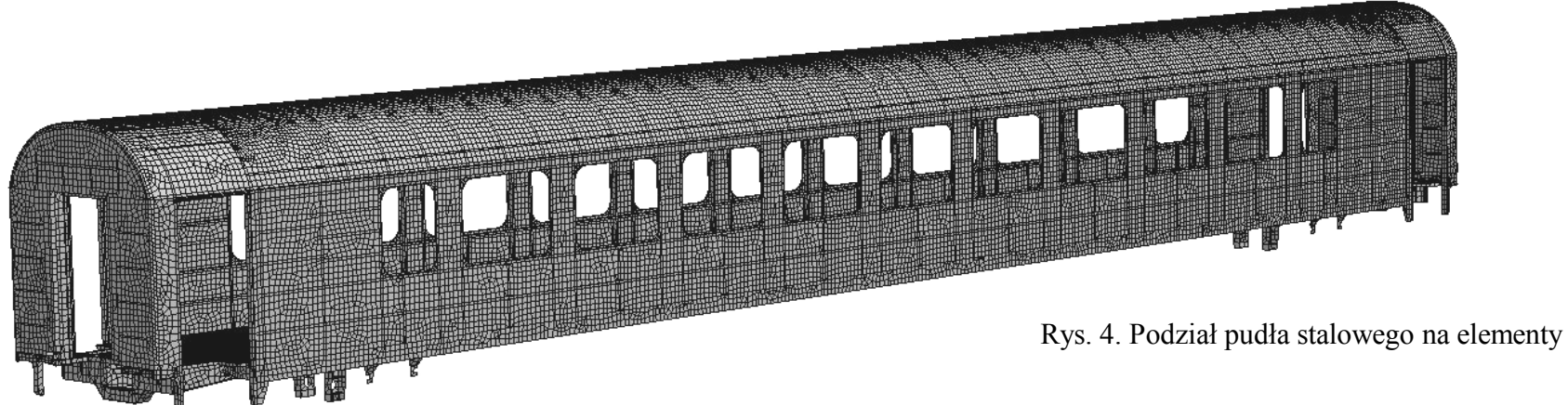

Rys.5. Przekrój wzdłużny części skrajnej wagonu - podział na elementy

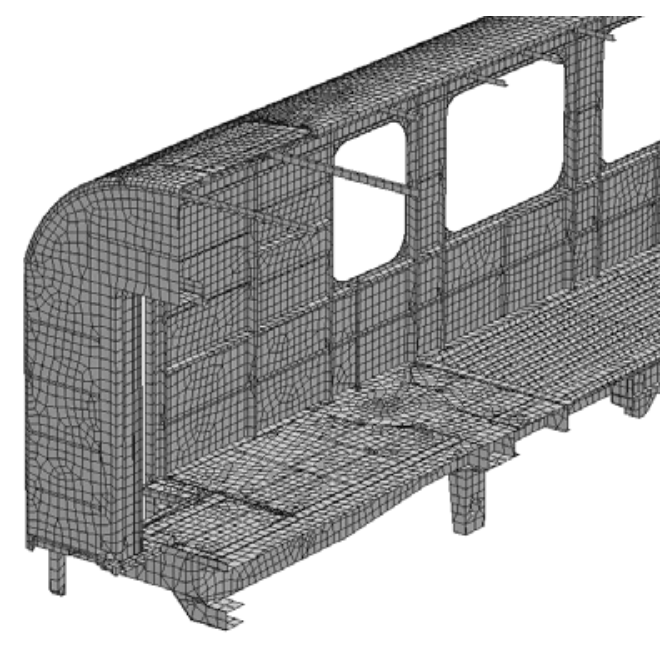


5. Wyniki badań numerycznych oraz ich wstępna ocena

W pierwszym etapie badań numerycznych uzyskano następujące formy i związane z nimi częstotliwości drgań strukturalnych pudła stalowego, które są przedstawione w tabeli 1 .

Częstotliwości i formy drgań własnych pudła wagonu

Tabela 1

\begin{tabular}{|c|r|l|}
\hline Oznaczenie & $\begin{array}{c}\text { Częstotliwość } \\
{[\mathrm{Hz}]}\end{array}$ & \multicolumn{1}{|c|}{ Forma drgań } \\
\hline F1 & 4,63 & $\begin{array}{l}\text { „rombowanie” przekroju } \\
\text { poprzecznego - postać 1 }\end{array}$ \\
\hline F2 & 8,75 & zginanie pionowe \\
\hline F3 & 10,2 & $\begin{array}{l}\text { zginanie poprzeczne - } \\
\text { postać 1 }\end{array}$ \\
\hline F4 & 10,37 & $\begin{array}{l}\text { „rombowanie” przekroju } \\
\text { poprzecznego - postać } \\
\text { 2a }\end{array}$ \\
\hline F5 & 10,61 & $\begin{array}{l}\text { „rombowanie” przekroju } \\
\text { poprzecznego - postać } \\
\text { 2b }\end{array}$ \\
\hline F6 & 11,25 & pulsacja - postać 1 \\
\hline F7 & 11,5 & skręcanie \\
\hline F8 & 12,97 & pulsacja - postać 2 \\
\hline F9 & 15,11 & pulsacja - postać 3 \\
\hline F10 & 15,70 & $\begin{array}{l}\text { zginanie poprzeczne - } \\
\text { postać 2 }\end{array}$ \\
\hline
\end{tabular}

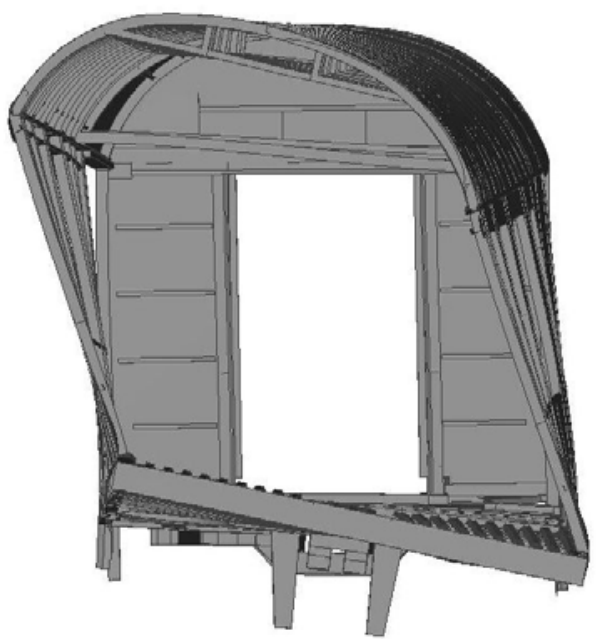

Rys.6. „Rombowanie” przekroju poprzecznego pudła F1
Pod pojęciem pulsacji rozumie się rodzaj deformacji pudła polegający na wybrzuszaniu lub zapadaniu się ścian bocznych i dachu (analogia do oddychania).

Szczególnie niebezpieczną formą drgań jest ,rombowanie" przekroju poprzecznego przekroju pudła F1 (najniższa częstotliwość), które wzbudzane jest przez wichrowatość toru (reakcja zawieszenia wtórnego) oraz przez wężykowanie obrotowe wózków (reakcja amortyzatorów wężykowania). Częstotliwość $4,63 \mathrm{~Hz}$ tej formy drgań pokrywa się z zakresem częstotliwości wężykowania obrotowego wózków. „Rombowanie” przekroju poprzecznego pudła F1 jest przedstawione na rys.6.

Niebezpieczeństwo związane jest tu z ryzykiem częściowej, a być może nawet całkowitej, utraty funkcji tłumienia drgań przez amortyzatory wężykowania obrotowego, prowadzace do drastycznego obniżenia prędkości krytycznej ze względu na stateczność biegu wózków. $Z$ tego powodu ta forma drgań wymaga bliższego rozpatrzenia $w$ ramach drugiego etapu badań numerycznych. Kolejna formą drgań strukturalnych pudła stalowego, interesująca ze względu na stosunkowo niską częstotliwość, jest zginanie pionowe F2. Częstotliwość ta może sprawiać pewien kłopot ze względu na spodziewaną bliskość częstotliwości drugiej postaci pionowych drgań własnych zawieszenia, który jednak nie ma związku z bezpieczeństwem jazdy, a może co najwyżej mieć wpływ na poziom komfortu jazdy, odczuwany przez pasażerów. Można stwierdzić, ze ta forma drgań nie wymaga podejmowania obecnie jakiś działań interwencyjnych, jednak warto mieć tą kwestię na uwadze w perspektywie przyszłych konstrukcji wagonowych.

Pozostałe formy drgań strukturalnych pudła stalowego mają częstotliwości powyżej $10 \mathrm{~Hz}$ i nie są narażone na żadne sprzężenia. W związku z tym nie wymagaja one bliższego zainteresowania. Formy drgań strukturalnych pudła stalowego $\mathrm{w}$ widoku $\mathrm{z}$ boku, z góry oraz ogólnym są przestawione odpowiednio na rys.7,8 i 9.

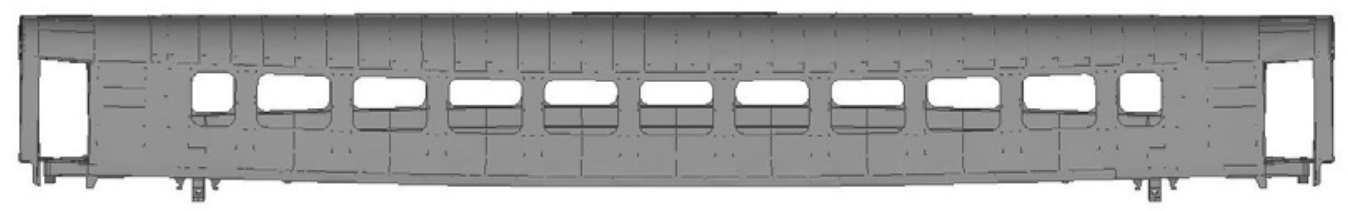

F2

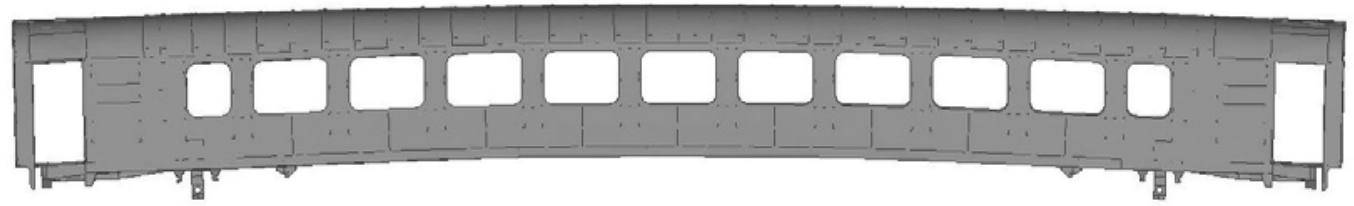

F3

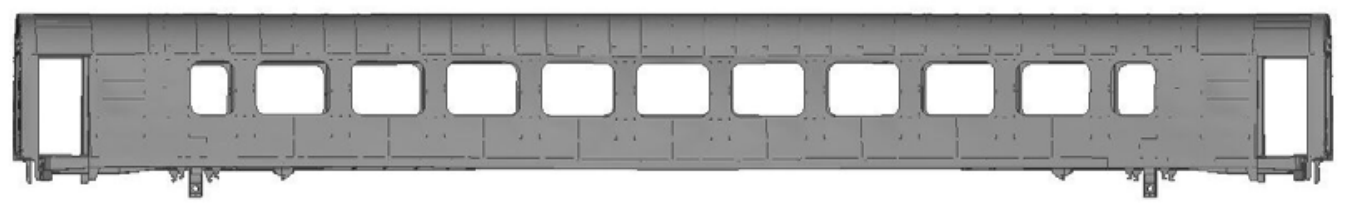



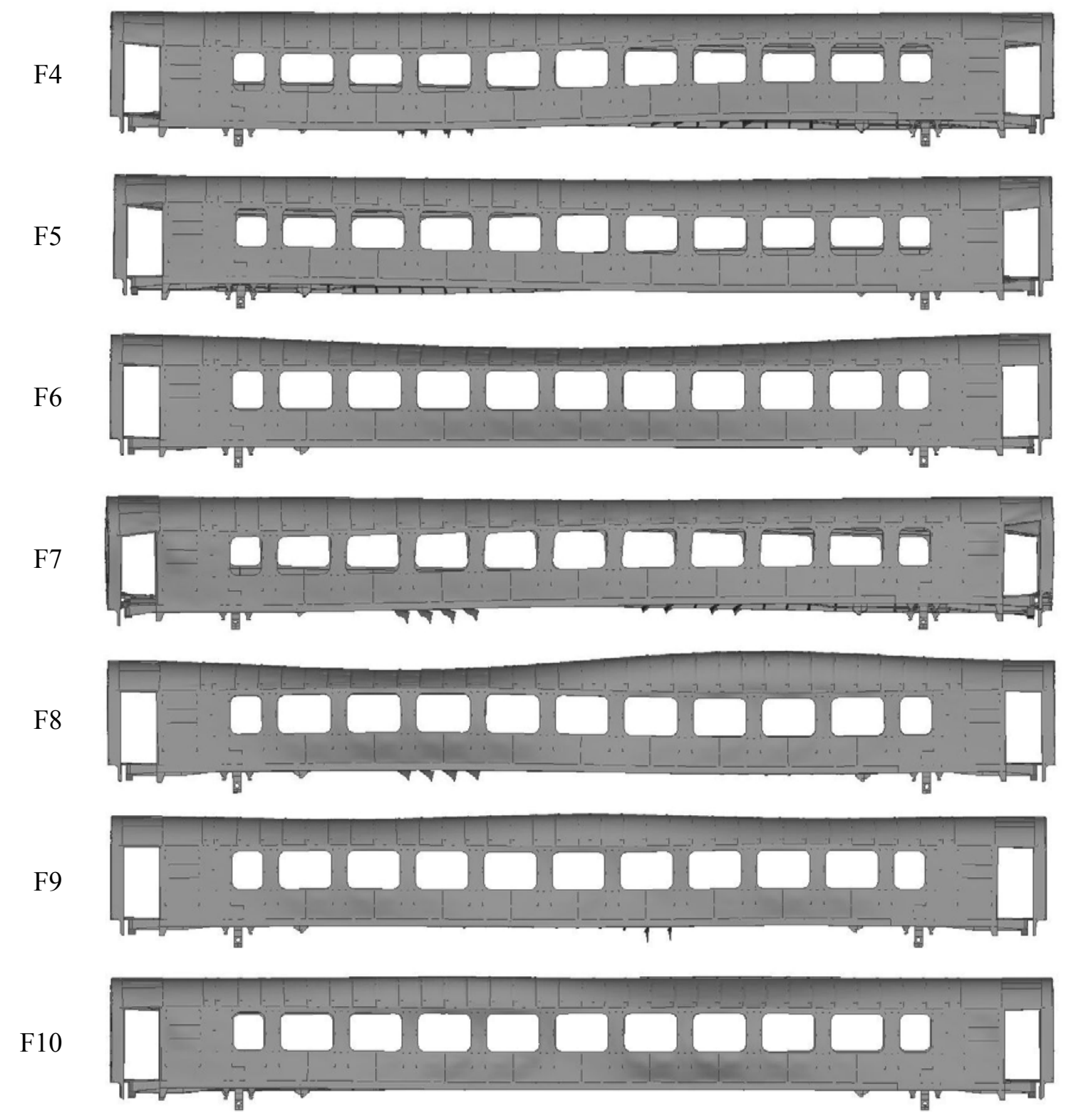

Rys. 7. Formy drgań własnych pudła - widok z boku

F1

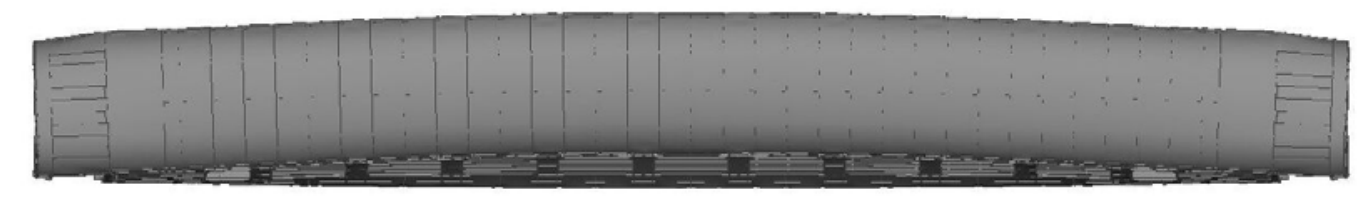

F2

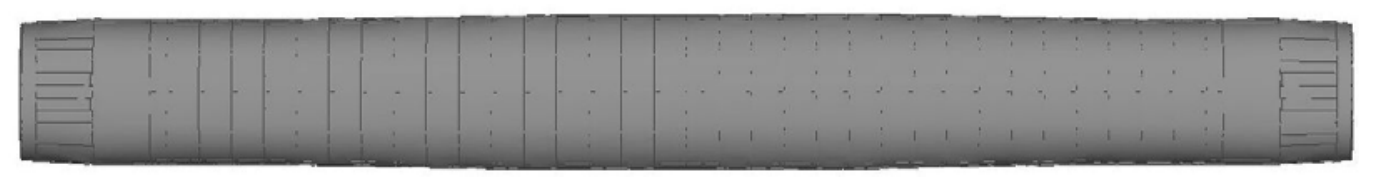

F3

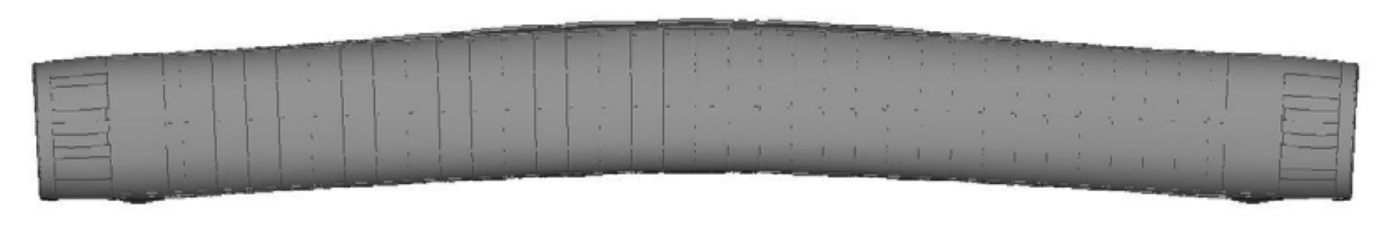




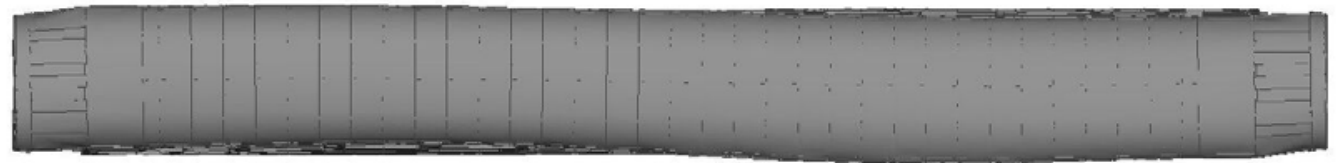

F5

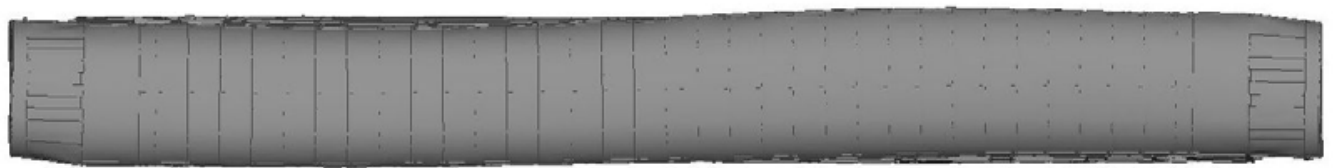

F6

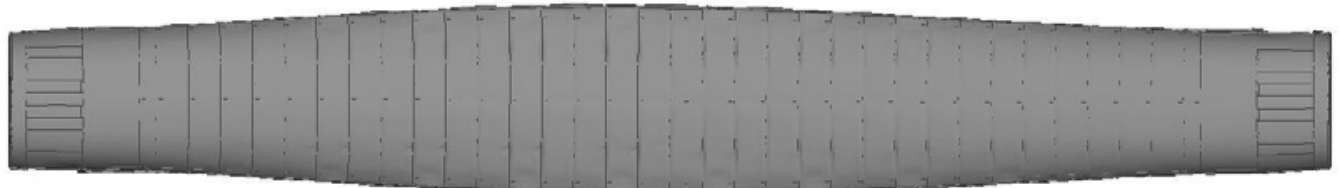

F7

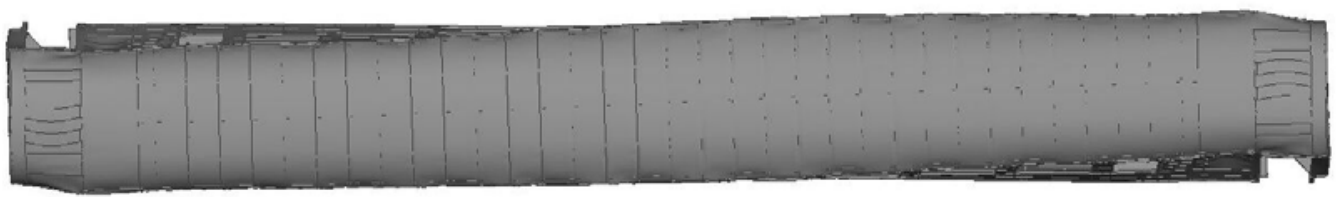

F8

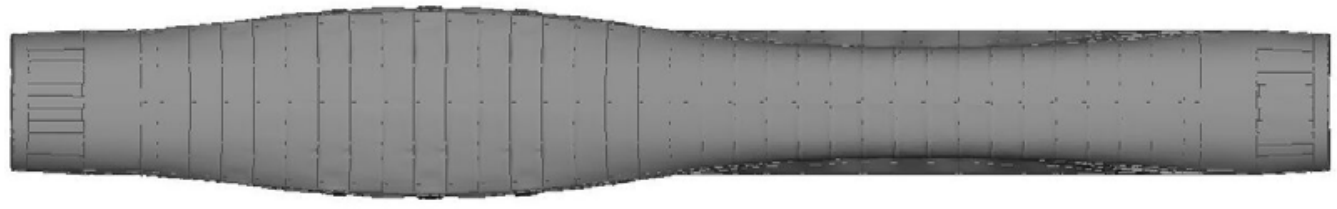

F9

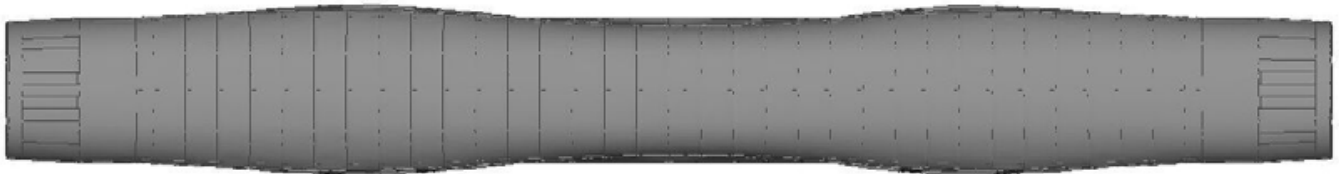

F10

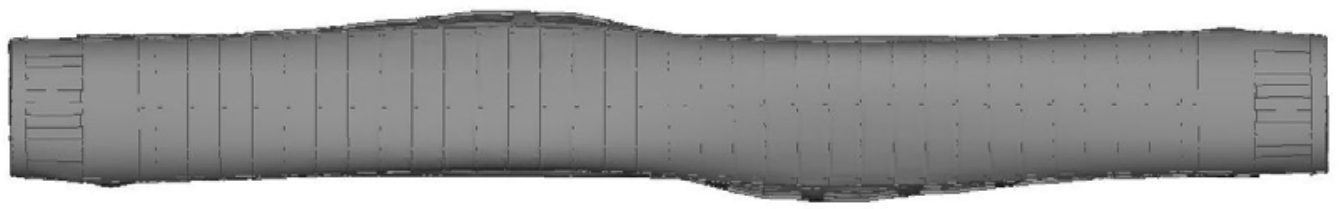

Rys.8. Formy drgań własnych pudła - widok z góry

F1

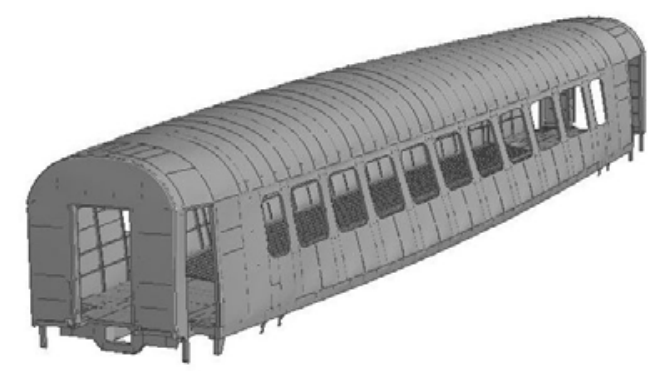

F3

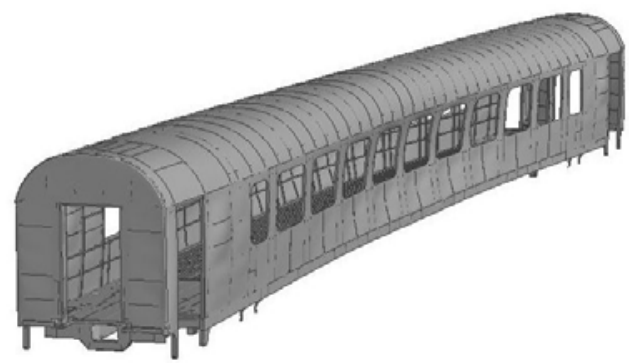

F2

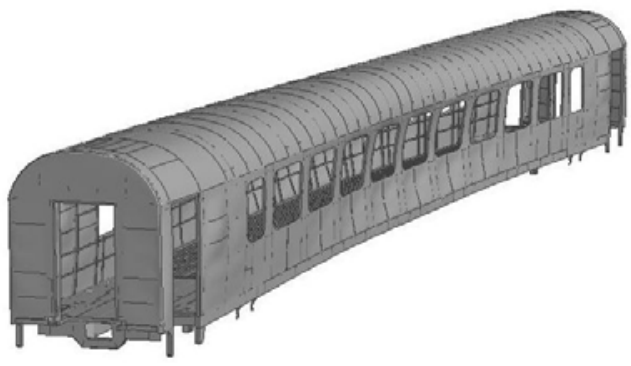

F4

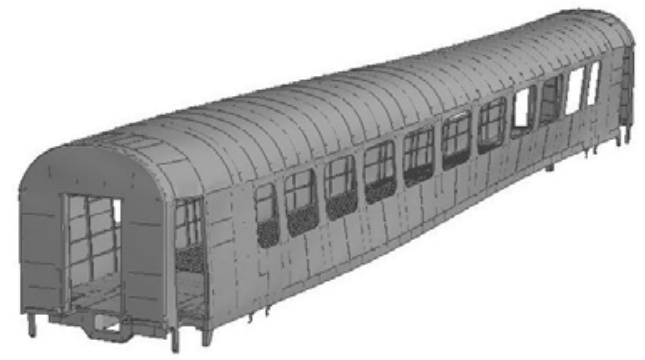


F5

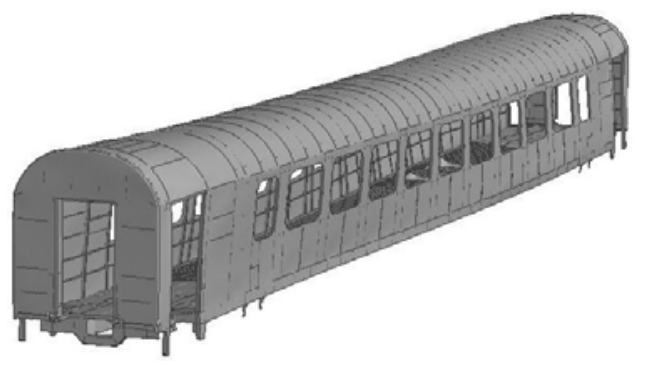

F7

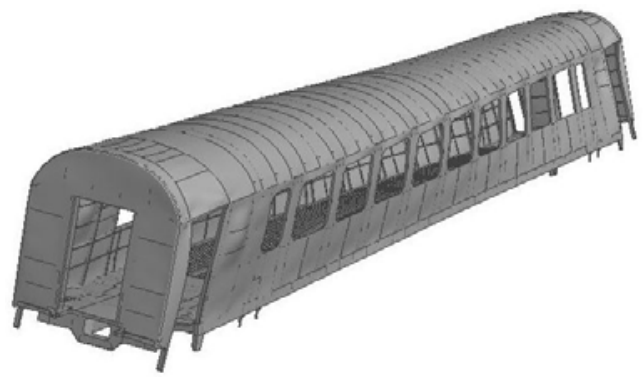

F9

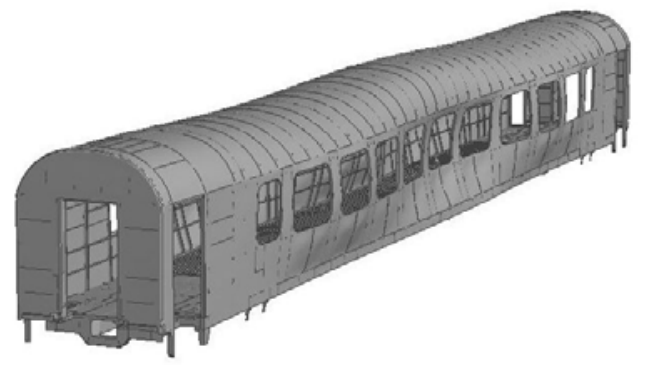

F6

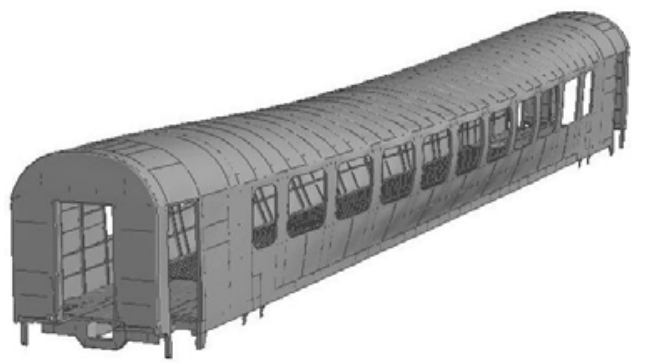

F8

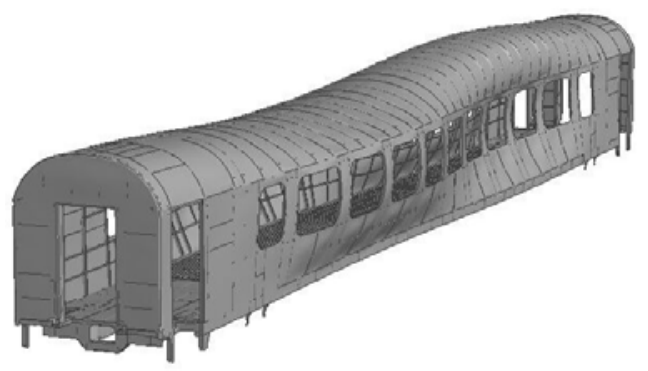

F10

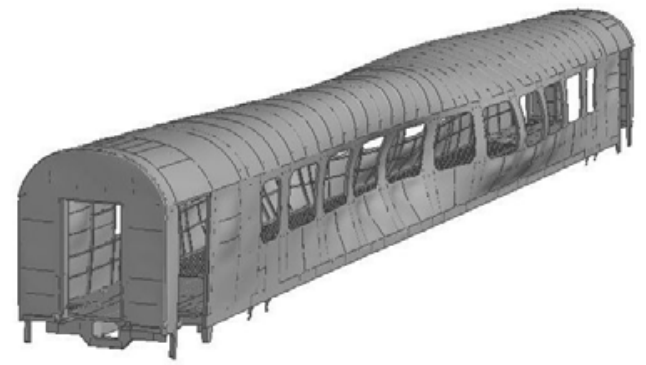

Rys. 9. Formy drgań własnych pudła - widok ogólny

W drugim etapie badań numerycznych wyznaczono relację zachodzącą między siłami harmonicznymi, reprezentującymi siły generowane przez amortyzatory wężykowania obrotowego wózków, a wzbudzanymi przezeń drganiami strukturalnymi pudła stalowego.

W oparciu o analizę modalną wyznaczono wielkości odkształceń struktury stalowej pudła w miejscach mocowania amortyzatorów wężykowania $\mathrm{w}$ zależności od częstotliwości wymuszeń, co pokazano na rys. 10.

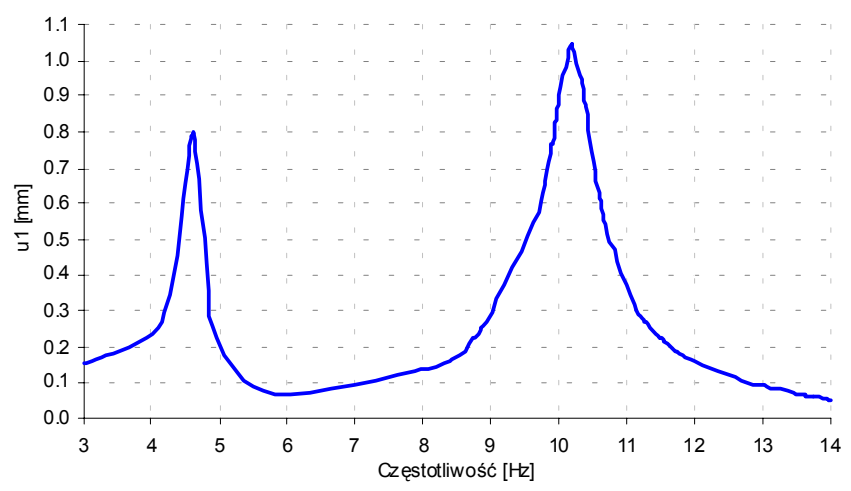

Rys.10. Wykres wzdłużnego przemieszczenia wspornika mocowania amortyzatora wężykowania na pudle stalowym wagonu w funkcji częstotliwości
Interesująca jest wyłącznie pierwsza częstotliwość rezonansowa 4,63 Hz, dotyczaca formy drgań F1, dla której odkształcenie (ugięcie w kierunku działania siły harmonicznej) wynosi $0,8 \mathrm{~mm}$. Ugięcie to jest równoznaczne ze stratą skoku roboczego amortyzatora wężykowania, którą należy uznać za znaczącą w kontekście wytracania energii wężykowania obrotowego wózków

\section{Wnioski}

Z pracy [2] wynika, że częstotliwość wężykowania wózków w przedmiotowym wagonie może osiagać poziom $6,5 \mathrm{~Hz}$. Ilustruje to diagram krzywych pierwiastkowych pochodzący z w/w pracy (rys. 11).

Częstotliwość wężykowania ok. $6,5 \mathrm{~Hz}$ występuje już przy prędkości jazdy wagonu $280 \mathrm{~km} / \mathrm{h}$. Na podstawie tego diagramu szacuje się, że częstotliwość wężykowania równa najniższej częstotliwości drgań strukturalnych pudła (forma F1 - ,rombowanie” przekroju) wynoszącej $4,63 \mathrm{~Hz}$ wystąpi przy prędkości jazdy rzędu $200 \mathrm{~km} / \mathrm{h}$. Można więc spodziewać się, że już przy tej prędkości jazdy przedmiotowy wagon będzie zachowywał się niestatecznie, co potwierdza zasadność wcześniej wysuniętych obaw.

W związku z tym konieczne jest zastosowanie odpowiednich środków zapobiegawczych. W związku $\mathrm{z}$ powyższym oraz $\mathrm{w}$ oparciu o spostrzeżenia 
poczynione w punkcie 5 niniejszej pracy przedstawia się następujące wnioski:

$>$ struktura pudła stalowego wagonu typu 150A jest niewystarczająco sztywna w kontekście skutecznego funkcjonowania systemu thumienia wężykowania obrotowego wózków

$>$ aby zapewnić konieczną skuteczność w/w systemu należy zastosować środki konstrukcyjne prowadzące do podwyższenia częstotliwości formy F1 drgań strukturalnych pudła (,rombowanie" przekroju poprzecznego)

$>$ w perspektywie przyszłych konstrukcji wagonowych należy dazżyć do podwyższenia formy F2 drgań strukturalnych pudła (zginanie pionowe).

Aby zrealizować drugi wniosek należy usztywnić pudło w taki sposób, aby zdecydowanie obniżyła się jego podatność na „rombowanie” przekroju poprzecznego. Najprostszym rozwiązaniem w sensie modelowym jest związanie całego przekroju poprzecznego położonego $\mathrm{w}$ środku długości wagonu za pomoca przegrody poprzecznej. Dla potrzeb badawczych przyjęto, że będzie to membrana stalowa o grubości $3 \mathrm{~mm}$. Rozwiązanie takie, pokazane na rys. 12, poddano ponownie procedurze obliczeniowej uzyskując niżej podane wyniki.
Wyniki uzyskane $\mathrm{w}$ trakcie ponownych badań analitycznych zamieszczono $\mathrm{w}$ tabeli 2.

Częstotliwości i formy drgań własnych pudła wagonu wzmocnionego przegrodą

Tabela 2

\begin{tabular}{|c|c|l|}
\hline Oznaczenie & $\begin{array}{c}\text { Częstotliwość } \\
{[\mathrm{Hz}]}\end{array}$ & Forma drgań \\
\hline F1p & 8,53 & zginanie pionowe \\
\hline F2p & 10,15 & zginanie poprzeczne \\
\hline F3p & 10,34 & $\begin{array}{l}\text {,rombowanie" przekroju } \\
\text { poprzecznego }\end{array}$ \\
\hline F4p & 11,72 & skręcanie \\
\hline F5p & 12,84 & pulsacja \\
\hline F6p & 13,07 & zginanie poprzeczne 2 \\
\hline
\end{tabular}

Formy drgań własnych pudła stalowego wagonu w widoku $\mathrm{z}$ boku, $\mathrm{z}$ góry oraz ogólnym przedstawiono odpowiednio na rys.13, 14 oraz 15.

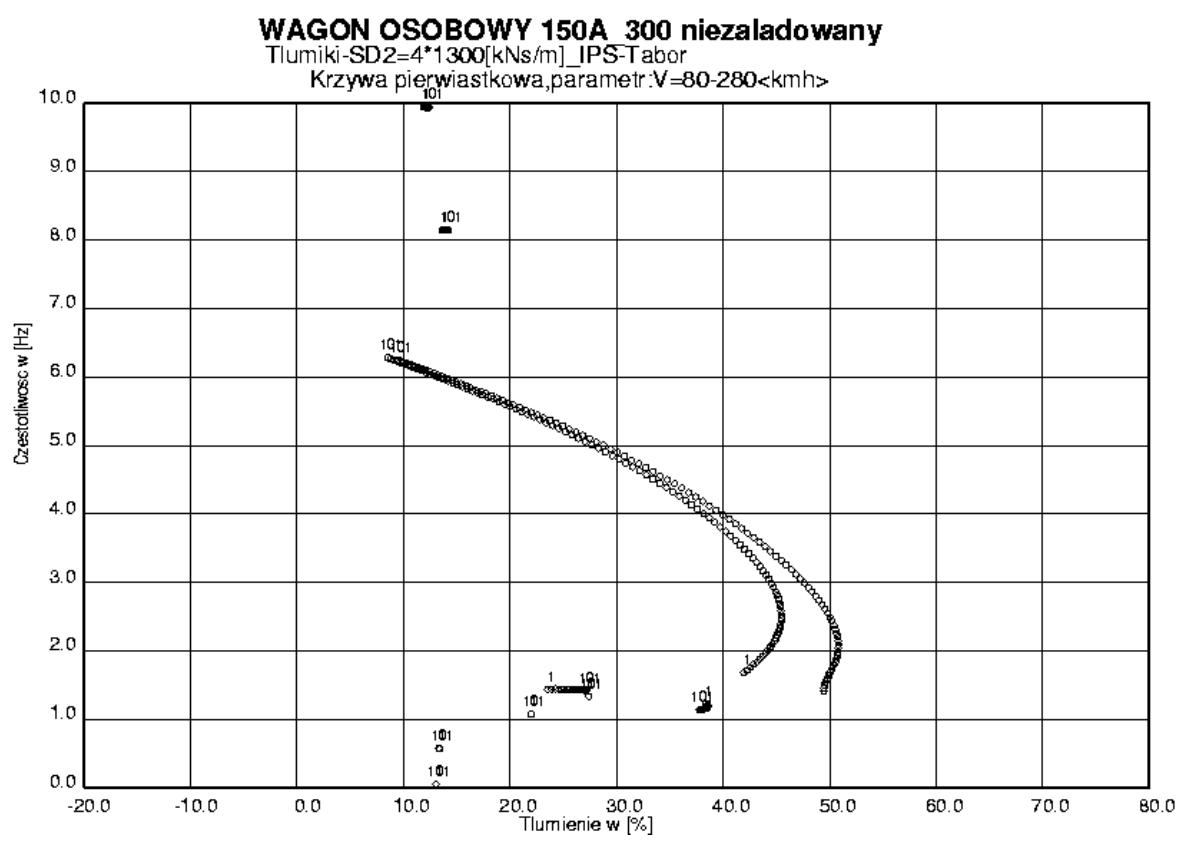

Rys. 11. Krzywa pierwiastkowa

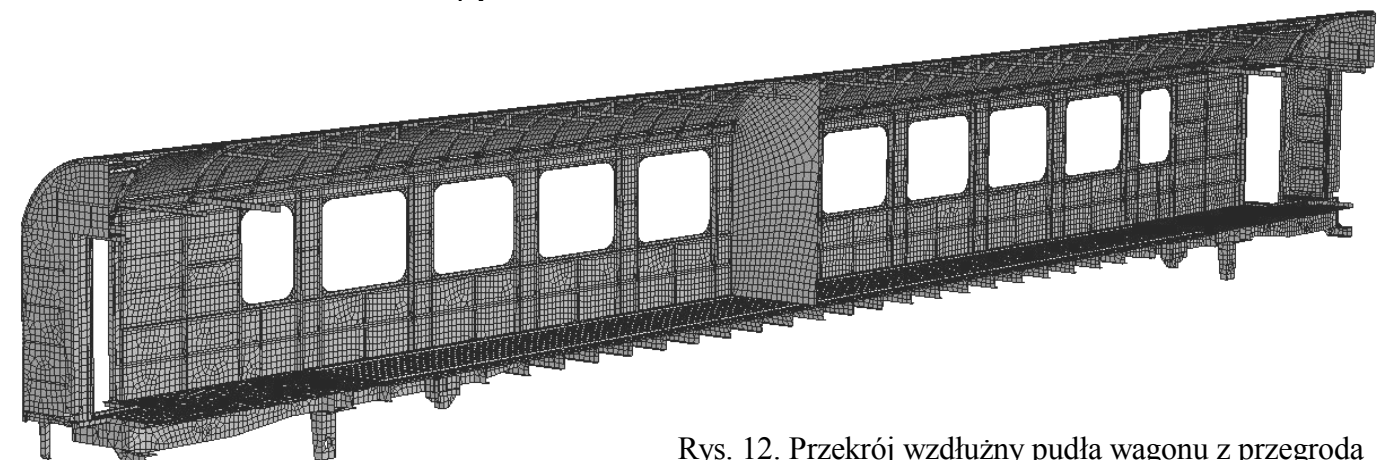

Rys. 12. Przekrój wzdłużny pudła wagonu z przegrodą 
F1p

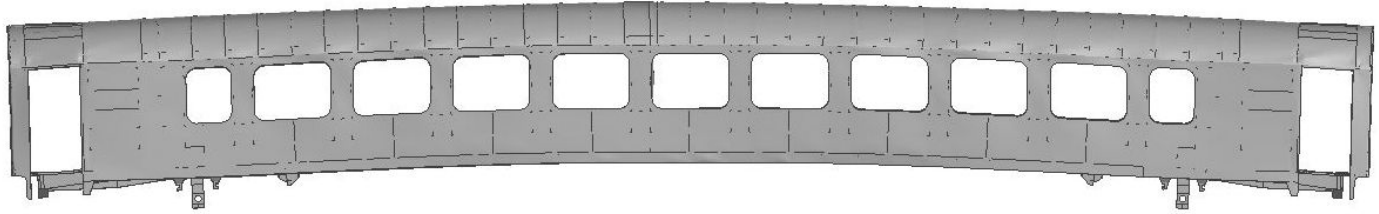

F2p

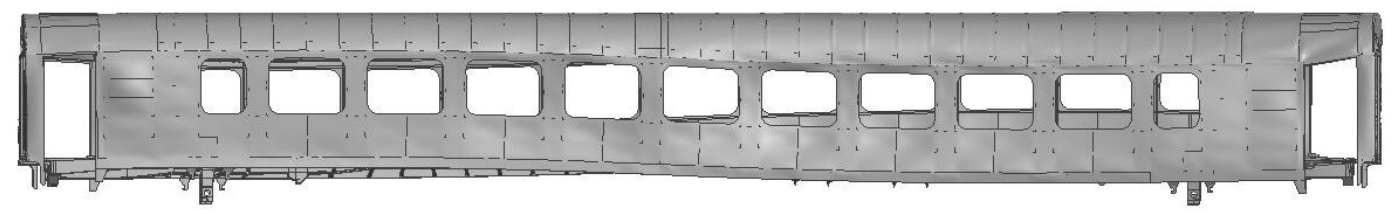

F3p

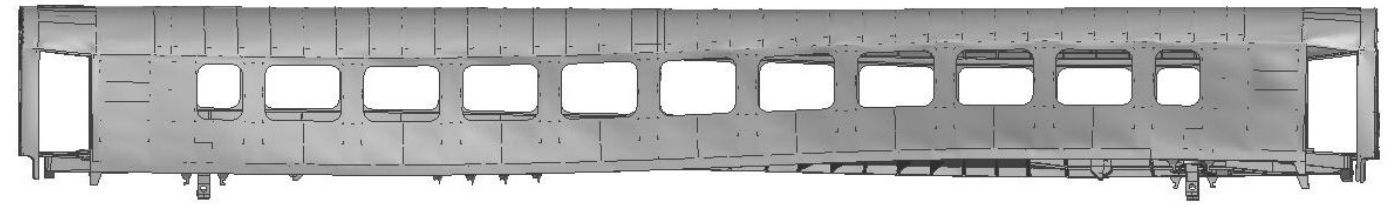

F4p

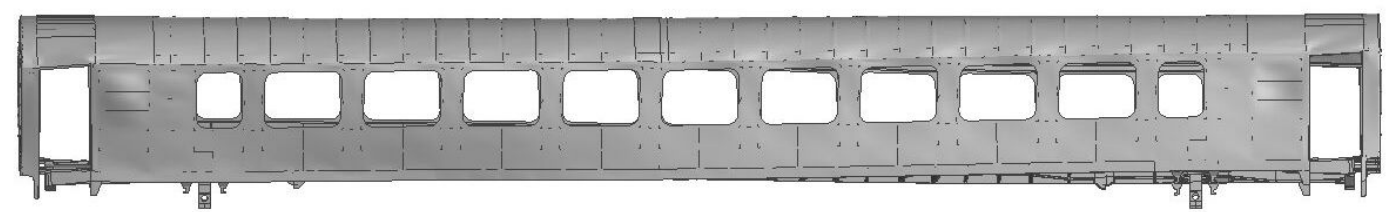

F5p

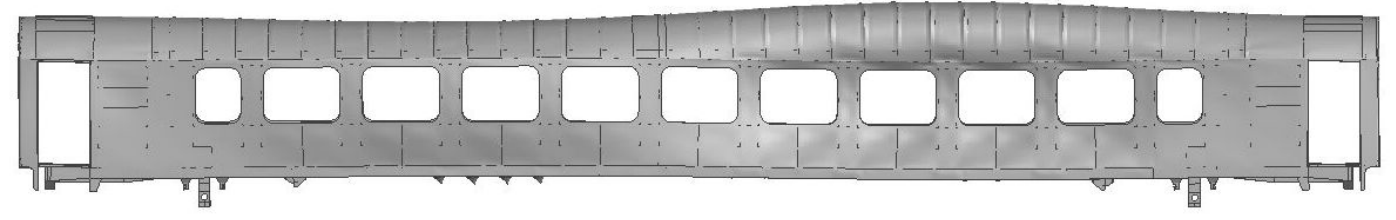

F6p

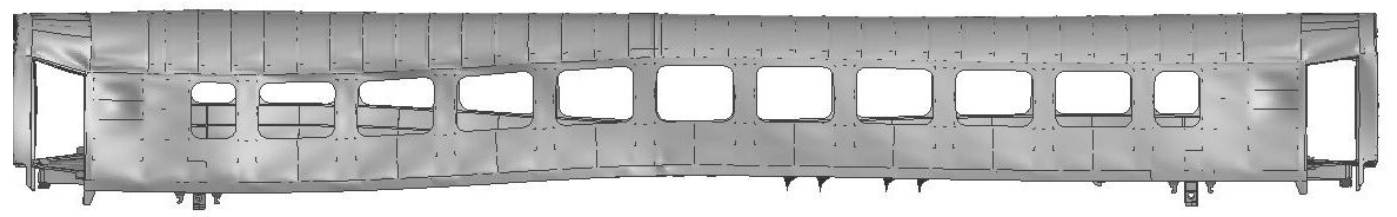

Rys. 13. Formy drgań własnych pudła - widok z boku

F1p

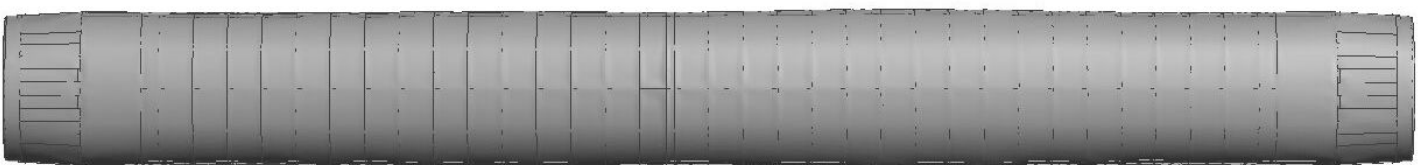

F2p

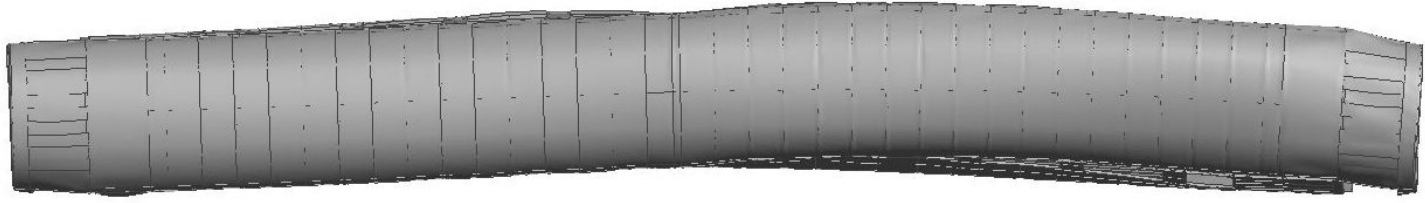

F3p

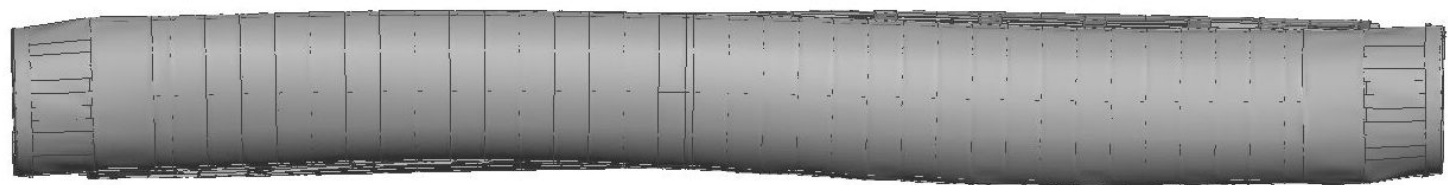


F4p

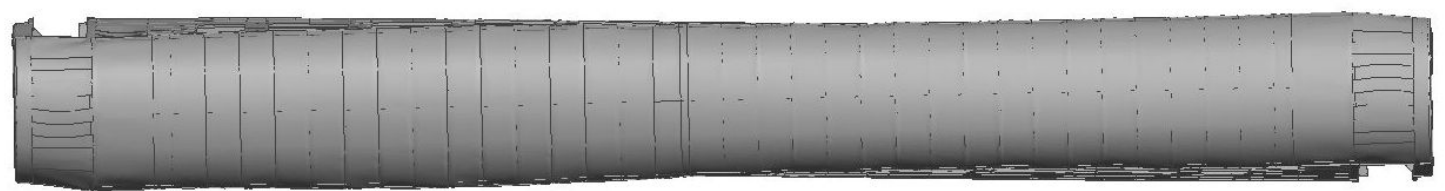

F5p
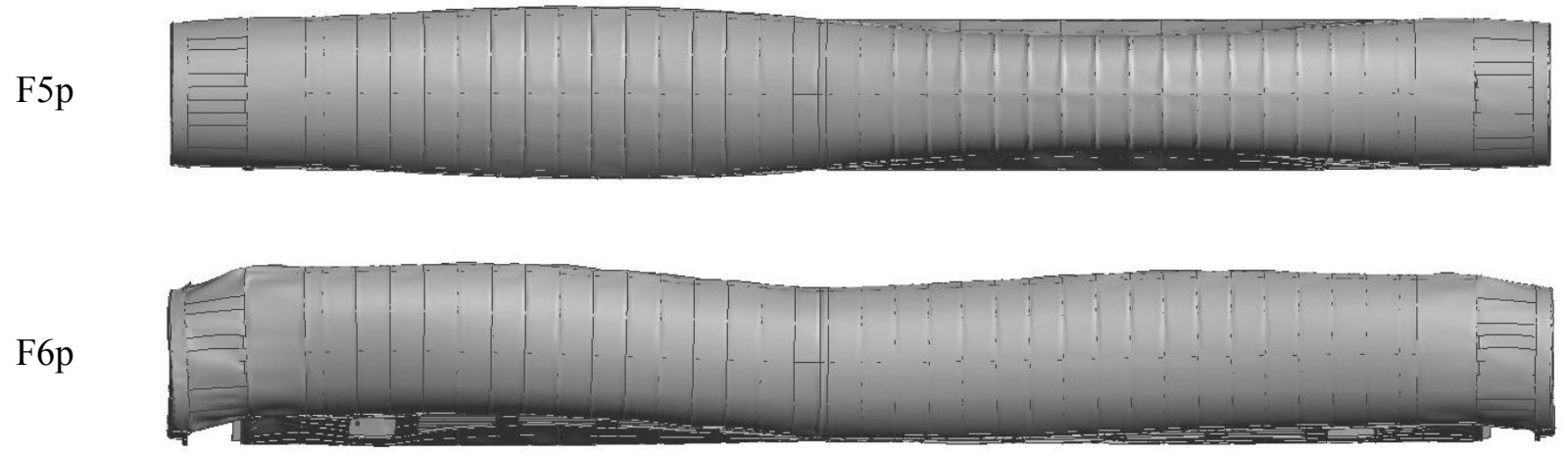

Rys. 14. Formy drgań własnych pudła - widok z góry

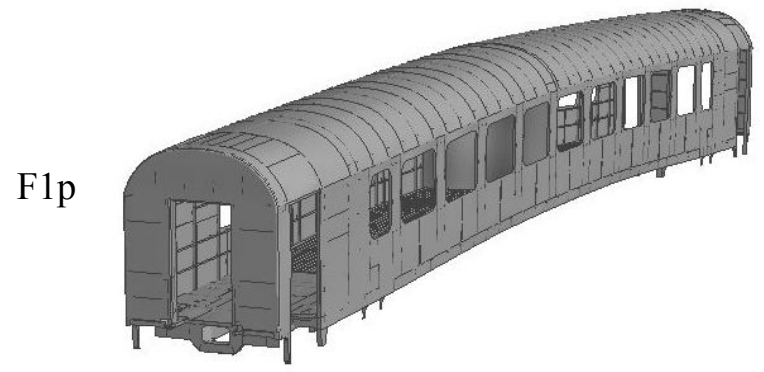

F2p
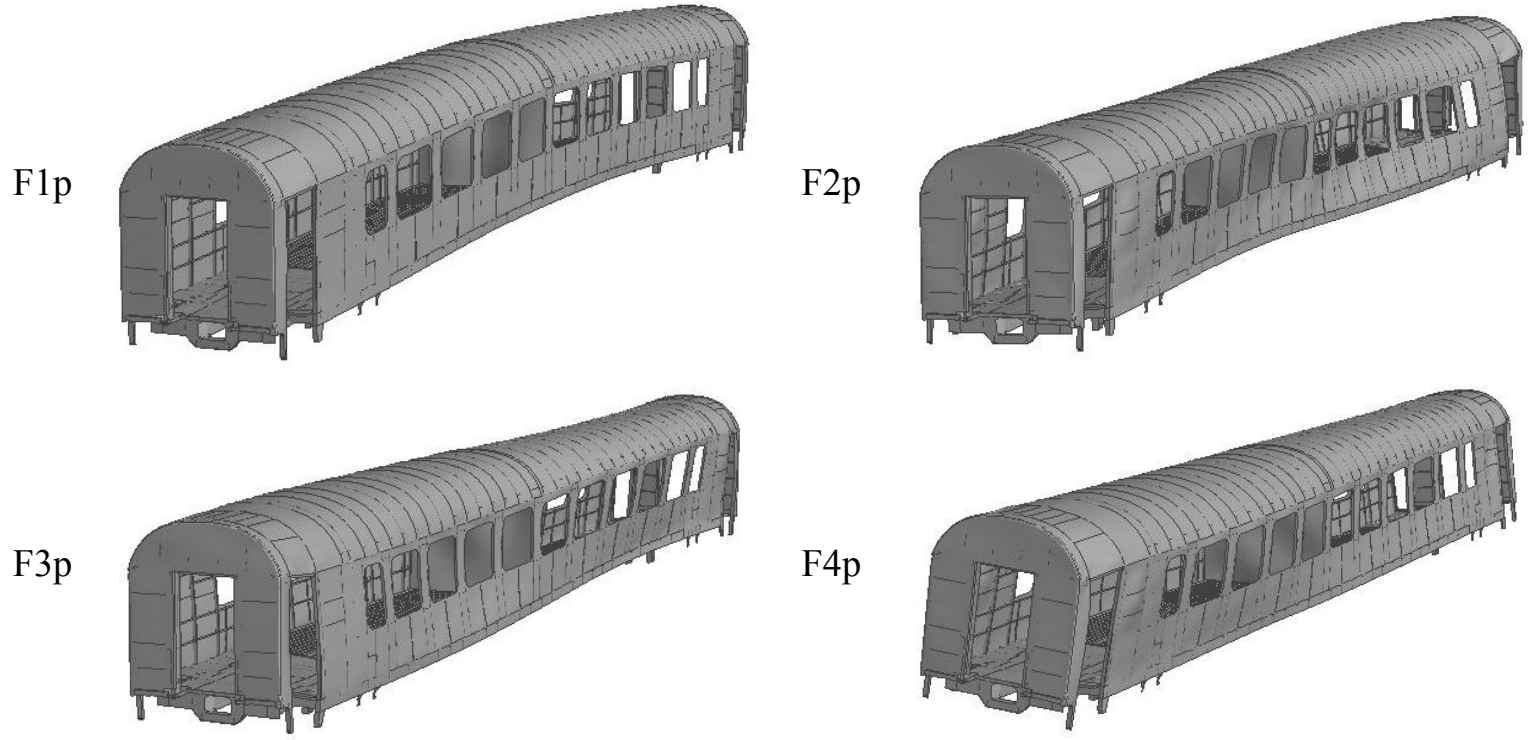

F4p
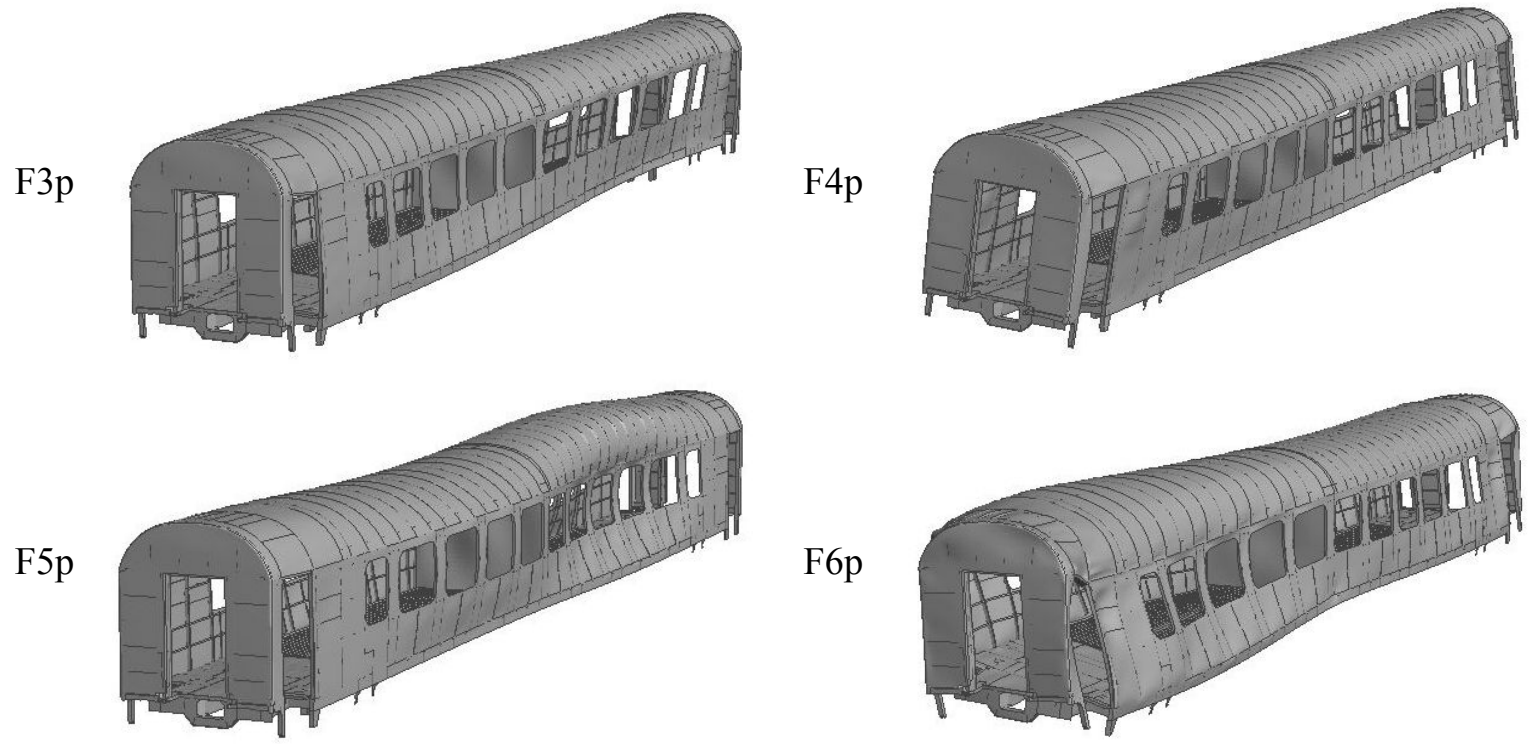

Rys. 15. Formy drgań własnych pudła - widok ogólny 


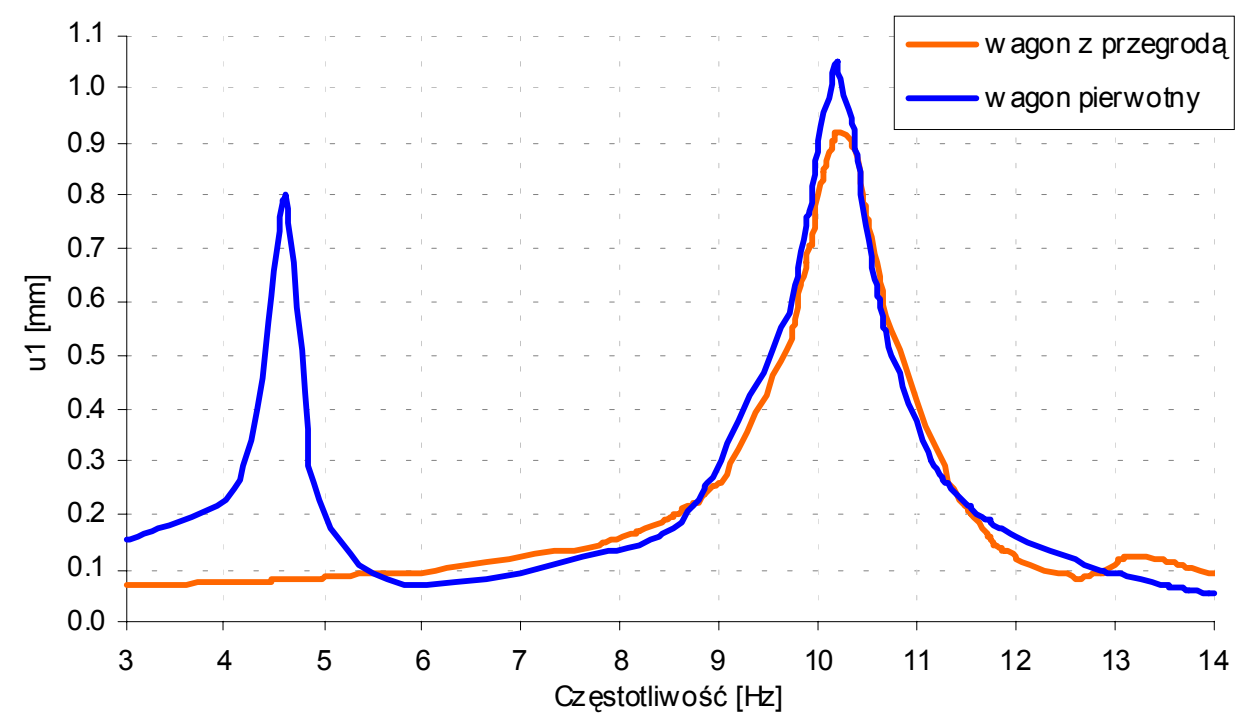

Rys. 16. Wykres wzdłużnego przemieszczenia wspornika w funkcji częstotliwości

Wykres przemieszczania wspornika amortyzatora wężykowania $\mathrm{w}$ miejscu połączenia $\mathrm{z}$ pudłem stalowym przedstawiono na rys. 16.

W rezultacie zanotowano wzrost częstotliwości formy F1 drgań strukturalnych pudła z 4,63 Hz do $10,34 \mathrm{~Hz}$ (po wprowadzeniu wzmocnienia formę tę oznaczono jako F3p), co dowodzi skuteczności zaproponowanego rozwiązania i pozwala sformułować wniosek, że wzmocnienie struktury stalowej pudła na ,rombowanie" przekroju poprzecznego za pomocą równoważnika membrany stalowej o grubości $3 \mathrm{~mm}$ położonej $\mathrm{w}$ środku długości wagonu jest skutecznym środkiem konstrukcyjnym, który spełnia zadanie utrzymania własności dynamicznych na oczekiwanym poziomie. Niniejsza analiza dowiodła, ze zagadnienie opracowania koncepcji wózka, przystosowanego do wysokich prędkości obejmuje również prace koncepcyjne związane $\mathrm{z}$ właściwą konstrukcją nadwozia wagonu osobowego. Przyczyna niewłaściwej dynamiki wagonu jako całości, może znajdować się w niewłaściwej konstrukcji nadwozia wagonu, przy prawidłowo skonstruowanym wózku tocznym.

\section{Literatura}

[1] ABAQUS Analysis User's Manual, ABAQUS Inc, 2003

[2] OR-9228:Obliczenia symulacyjne dynamiki i bezpieczeństwa ruchu wagonu pasażerskiego typu UIC-Z wyposażonego $w$ wózki typu llANc. IPS „TABOR” Poznań, grudzień 2007.

[3] OR-9239: Obliczenia wytrzymatości modyfikowanej ramy wózka llANa. IPS,, TABOR"Poznań, maj-wrzesień 2007.

[4] PN-EN 14363:2005: Kolejnictwo. Badania własności dynamicznych przed dopuszczeniem pojazdów szynowych. 2007. 